\title{
Processed Food Exports from Developing Countries: Patterns and Determinants
}

\author{
by \\ Prema-Chandra Athukorala \\ and \\ Kunal Sen
}

\begin{abstract}
A noteworthy recent development in world trade is the rapid expansion of processed food exports. This development and its policy implications have received little attention in the literature on export-led industrialisation in developing countries (DCs). The purpose of this paper is to redress this oversight firstly by providing an overview of the growth patterns of processed food exports and then examining the determinants of inter-country differences in growth performance. The results point to the growing importance of food manufacturing as a dynamic export line for many DCs. There is also evidence that the policy regime is far more important than resource endowments and other country-specific factors in explaining inter-country differences in export success in this product area, as in the case of conventional manufactured exports.
\end{abstract}

JEL Classification: F14, O13 


\section{Processed Food Exports from Developing Countries: Patterns and Determinants*}

\section{Introduction}

The motivation for this paper stems from the on-going debate on market-oriented policy reforms and industrial restructuring in Chile over the past two decades. Following remarkable economic success achieved through market-oriented policy reforms since the mid-1980s, the Chilean economy is now widely held as a model for other developing countries (Edwards 1995). The successful expansion of exports is considered one of the key factors that contributed to this impressive growth performance. Compared to other export success stories in the developing world, there is, however, a striking peculiarity in the emerging export pattern in Chile. Despite virtual elimination of the anti-export bias in the incentive structure of the economy, according to the standard definition used in trade flow analysis, ${ }^{1}$ the expansion of manufactured exports has not "materialised to any significant extent" (Helleiner 1994, p. 15) and much of rapid export growth has continued to come from the so-called 'primary sector'. ${ }^{2}$ Critics of market-oriented policy reforms draw upon this 'peculiar' Chilean experience to support the view that, under depressed world market conditions, "radical liberalisation may not encourage restructuring" (Amsden and Van Der Hoeven 1996, p. 520). This interpretation is, however, inconsistent with the pattern observed in an analysis of the Chilean national trade data which are compiled according to the broader International Standard Industry Classification (ISIC); the impetus for export expansion has come not from traditional primary goods but from new agro-based manufacturing activities, in particular various fish preparations and

\footnotetext{
* We thank Tina Chen for able research assistance.

1 According to this definition manufactured exports consist of all commodities belonging to Sections 5 though 8 less items 68 (non-ferrous metal) in the Standard International Trade Classification - SITC). Processed/manufactured food items are classified together with the related primary products.

2 The share of conventional (SITC-based) manufactures in total merchandise exports amounted to 5.6 percent in 1994, up from 4.5 percent in the mid- 1980s.
} 
processed fruits. While labour- intensive manufactures too have demonstrated impressive growth dynamism in absolute terms, this has been dwarfed by the more dramatic growth record of processed agricultural goods. There is evidence that these new product lines have many positive attributes according to which the contribution of manufactures to the objectives of industrialisation are normally evaluated. These include economy-wide linkages, important learning effects emanating from the mastery of new production technology, higher productivity, international marketing effort and entrepreneurial skills involved in export success (Meller 1995).

Is this impressive growth of processed food exports a peculiar Chilean phenomenon, or does it point to an export-success story in which market-oriented reforms have enabled the Chilean economy to benefit from an emerging trend in world trade? It could well be that other developing countries which are endowed in agricultural, livestock and marine resources too have begun to benefit (or have the potential to benefit) from this phenomenon, but the available analyses of trade patterns based on the conventional (SITC-based) commodity classification system have failed to detect this important development (see note 1). This paper presents preliminary results of our research motivated by these considerations. We believe that the results of our investigation has important implications for the current debate on the market opportunities faced by developing countries in the process of export-oriented industrialisation as well as the appropriateness of the standard practices in trade flow analysis.

The approach of the paper is as follows. In Section 2 a concordance is developed between SITC and ISIC classification systems to delineate processed food from primary agricultural products (Section 2). Section 3 analyses the relative importance of processed food in total exports and their composition and product characteristics for a set of developing countries for which systematic data are available for studying the issue at hand. Section 4 attempts to examine the determinants of inter-country variations in food 
export growth. The major focus of the econometric analysis in the section is on the relative importance of policy regime versus resource endowments and the level of development in explaining inter-country differences in export growth. A final section summarises the findings of the study, derives policy inferences and makes suggestions for further research.

\section{Data Compilation}

The United Nation (UN) trade data system, which is the common source of study of international trade patterns, is based on the Standard International Trade Classification (SITC). The SITC does not permit the direct identification of industrial products based on agricultural (and other natural) resources. To deal with this classification problem, we cross-referenced the SITC commodity listing at the 5-digit level to that of the InternationaI Standard Industry Classification (a classification by industrial origin) at the 4-digit level, using the UN commodity concordance (UN 1994). ${ }^{3}$ The list of items covered in the study is reported in Table A1. Using this list, data were tabulated from UN trade data tapes (SITC Revision 3) held by the International Economic Data Bank (IEDB), Australian National University. Petroleum and petroleum-based products are excluded from the commodity coverage for obvious reasons.

To avoid selection bias, we started extracting data for all developing countries (96) covered in the UN data system. The countries finally chosen for the study (37 in number) are the ones for which data are available in the required form on a consistent basis for the period 1970-1994. Despite data availability, the city states of Hong Kong and Singapore are excluded from the country coverage as, given the nature of the resource endowment, food processing was never an export option available to them. ${ }^{4}$

\footnotetext{
${ }^{3}$ In the SITC system, processed food items are contained in divisions 0: food and beverages, 1: tobacco and 4: vegetable oils. The comparable sections in the ISIC system are industry groups 311 through 314 .

${ }^{4}$ A significant amount of processed food from other neighbouring resource-rich countries is routed through these counties as part of entre-port trade. They also undertake some final stage processing of these items.
} 


\section{Patterns and Product Characteristics}

\section{Patterns}

As is well-known, world merchandise trade over the past three decades has been characterised by the rapid growth of manufacturing exports. Based on the conventional (SITC-based) definition, their share in total exports increased from 66 per cent in 1970 to 81 per cent in 1994. This increase has been closely associated with the rapid expansion of manufacturing exports form developing countries. The developing-country share in world manufacturing exports increased from 6 per cent in 1970 to 24 per cent in 1994 (Table 1). Moreover, the share of manufacturing in total exports of developing countries increased from 27 per cent to 79 per cent between these two years.

While this feature of world merchandise trade is now well-documented in the literature, a feature that has attracted relatively less attention is the significant increase in the share of processed food in total non-manufactured exports (total merchandise exports less SITC manufactures). Their share in world non-manufacturing trade increased from 26 per cent in 1970 to 37 per cent in 1994 (Table 1). As in the case with manufacturing exports, the increase in this share is sharper for developing countries compared to that of developed countries. Between 1970 and 1994, the share of processed food in nonmanufacturing exports from developing countries increased from 23 per cent to 38 per cent compared to an increase from 28 per cent to 36 per cent recorded by developed countries.

A detailed examination of the factors behind the growth of processed food in world trade is beyond the scope of this paper. However, a priori reasoning and some scattered evidence suggest a number of factors. A widely observed feature of consumer behaviour in the global economy has been an increasing internationalisation of food habits' - the increased importance of processed items (canned fruits and vegetables, cereals and breakfast foods, etc.) in food consumption patterns in developed countries as well as in large sections of the populace in many developing countries. Factors such as 
international migration, the communications revolution and international tourism have contributed to this phenomenon. This may have provided a significant demand-side impetus to the growth of processed food exports from developing countries. On the supply-side, improvements in food technology, refrigeration facilities and transportation have made processed food items easily tradeable across national boundaries.

Not all developing countries have, however, shared in the growth of processed food exports in the world economy (Table 2). Among the 37 countries, we find that some countries have performed far better than others in this area. For example, Bangladesh, Bolivia, Chile, Indonesia, Korea, Malaysia and Thailand had annual growth rates close to or exceeding fifteen per cent in 1970-1994. ${ }^{5}$ In contrast, Cameroon, the Dominican Republic, Ghana, Nicaragua, Nigeria, Sudan, Senegal, Tanzania and Zambia exhibited annual growth rates of five per cent or less. There is some indication that generally countries belong to the high- and middle-income groups (following the World Bank classification) have performed better compared to countries in the low income category. Among the low-income countries, Bangladesh is a notable exception, with a growth rate of processed food exports that is more than double that that of any other low income developing country. ${ }^{6}$

Disaggregating exports by major category, we find that in general, the growth rate of processed food has been significantly higher than that of primary products (Table 2). Thus the overall country experience supports the view that increased importance of processed food in world trade is a universal phenomenon. ${ }^{7}$ The growth performance of conventional manufactured goods is generally superior, but a there is significant number of countries which have achieved higher or comparable growth in processed food exports. Interestingly, one observes a stronger correlation between manufacturing export growth and processed food export growth than between primary products export growth and

\footnotetext{
5 Bangladesh's growth rate is for the period 1975-1994.

6 Burundi is a clear outlier with respect to the growth of processed food exports due to the small base in 1970.

7 On this point, see also Teitel (1989) and Athukorala (1991).
} 
processed food export growth - the correlation coefficient between the former two was 0.41 as compared to a correlation of 0.34 for the latter two for the period 1970-1994. High-performing Asian economies such as Indonesia, Korea, Malaysia and Thailand, who have performed remarkably well in manufacturing exports, have also recorded impressive growth in processed food exports. It can be argued that for developing countries, the domestic policy regime is the key determinants of manufacturing export growth while resource endowments determine in great part export performance in primary products. Viewed from this perspective, the closer correlation between manufacturing and processed food exports than between primary and processed food exports provides some support for the hypothesis that the nature of the policy regime has played a more important role than resource endowments in contributing to the growth of processed food exports from developing countries. We test this hypothesis more explicitly in the next section.

The data reported in Table 2 also point to a high degree of country concentration of processed food exports. Five countries - Argentina, Brazil, Malaysia, Thailand and Taiwan- accounted for over 40 per cent of total exports of all developing countries in $1994^{8}$. However, the distribution has become more equal over time - the coefficients of skewness and kurtosis in 1994 were 2.1 and 4.0 respectively, as compared to 2.3 and 4.9 per cent respectively in 1970. This indicates that more and more developing countries have been participating in the world-wide expansion in processed food exports in recent years.

Table 3 summarises data on the relative importance of expresses processed food exports compared to a) total exports, b) total non-manufacturing exports, and c) total ISIC manufacturing exports for the individual countries in 1970, 1980, 1990 and 1994. For most countries, processed food as a share of non-manufacturing exports has increased sharply over the period 1970-1994. This pattern is particularly notable for countries with a superior overall export record during the period such as Chile, Thailand, Indonesia, Malaysia, Turkey, Tunisia, Guatemala, El Salvador and Sri Lanka. The importance of

\footnotetext{
${ }^{8}$ On this point, see also Islam (1988).
} 
processed food in overall export performance is, however, not clearly observable when their share in total exports is used as the performance criteria because of the superior performance of (conventionally defined) manufacturing exports. For most countries, the share of processed food in total exports has remained stable or even fallen over time. This is particularly evident in the case of middle and high income developing countries, where in several instances, growth of manufacturing exports has far exceeded the growth rate of processed food exports.

A comparison of the share of processed food in total manufactured exports defined according to the ISIC clearly suggest that the use of the conventional SITC based categorisation may lead to a serious underestimation of the manufacturing export potential in several developing countries. For 19 of the 37 countries, processed food have accounted for at least twenty per cent of total ISIC manufacturing exports in 1994. In general, however, countries which have experienced a sharp increase in manufacturing exports in recent years (in particular, the high performing Asian economies) have witnessed a steady decline in the share of processed food in total ISIC manufacturing exports as the manufacturing sectors of these countries gradually diversified into other product areas.

Table 4 presents data on the commodity composition of processed food exports form developing countries. A notable development revealed by the data is the remarkable shift in the commodity composition over time. Export growth in recent years has come mostly come from commodities that were relatively less important in the 1970s. The most prominent of the new dynamic items has been processed fish, whose share in total processed food exports from developing countries increased from 8.8 per cent in 1970 to 30.7 per cent in 1994. There is also been an increase in the share of preserved fruit in processed food over time, though not as spectacular as in the case of processed fish. On the other hand, shares of 'traditional' items such as meat products, sugar and molasses, animal feeds, tobacco products and vegetable oils have either fallen or fluctuated erratically over time. 
The shares of the two most dynamic components of processed food exports processed fish and preserved fruit - in total processed food exports of the sample countries are shown in Table 5. Interestingly, about 40 per cent of total processed food exports is accounted for by these two commodity categories for most developing countries. Also striking is the sharp increase in processed fish in total processed food exports in several developing countries. For 17 of the countries, processed fish alone accounted for 40 per cent of total processed food exports in 1994. However, while processed fish has clearly been the most dynamic processed food sector, disaggregated data for individual countries (not reported here) indicates that the commodity mix varies significantly across countries.

\section{Characteristics}

The emphasis on manufactured exports expansion in developing countries is rooted in the belief that compared to primary commodities, manufactured goods have some intrinsic characteristics which contribute to superior growth performance. Employment potential, terms of trade gains, knowledge and technology spill-overs are among the most emphasised of these characteristics. To what extent do processed food meet these criteria?

Regarding the employment potential of resource-based manufacturing in general, the received view based on standard trade theory (Heckscher-Ohlin model) is that an abundant supply of labour is not a key determinant of comparative advantage in international production (Roemer 1979, Findlay 1985). The dominant costs in the production process of resource-based products are capital charges and raw material inputs, and the most important factor substitution appears to be towards greater capital intensity to reduce raw material costs. Whether this generalisation is applicable to processed food is debatable. As we have already noted, there is no clear relationship between income levels (which is generally correlated with the availability of capital) and processed food export growth. Furthermore, unlike in the case of further processing of resources such as minerals and timber, final stages of food processing appear to be labour-intensive. This implies that the expansion of the processed food sector can have a 
strong positive effect on employment generation in the typical labour-surplus developing economy. While further research is needed on this subject, this view finds preliminary support from the factor proportion estimates for Malaysian manufacturing reported in Table 6. Note that in terms of the degree of labour-intensity, dynamic processed food items such as canned pineapple and fish products are not significantly different from wellknown labour-intensive manufactured goods such as semi-conductors and other electrical goods.

Whether export diversification will lead to terms of trade gains depends on the degree of income and price elasticities of demand for the commodities concerned. The data we have already analysed relating to overall demand trends suggest that processed food exports are superior to primary products in terms of these criteria. The results of the extensive analysis of the new dynamic agricultural exports by Islam (1988) and estimates of elasticities reported in Islam and Subramanian (1989) further corroborate this view. Preliminary results of our research- in- progress on agricultural exports from Thailand suggest that in terms of trade implications, processed fish and fruit exports closely resemble traditional manufactured goods.

We believe that in terms of 'spread effects', processed food would be even superior to conventional manufactured goods, which are by their very nature, are highly import-dependent. Processed food industries have a large domestic resource content and tend to be closely related to activities in the rural sector. In an interesting firm-level study of export performance in Chile, Meller (1995) comes up with the inference that in terms of knowledge spill-over, in particular learning through interaction with foreign buyers and improving quality standards in face of stringent export competition, agro-based manufacturing is comparable or even superior to a growth strategy based on the expansion of conventional labour intensive manufactured goods. 


\section{Determinants}

From the study of the relative performance of developing countries in processed food exports in the previous section, we drew the hypothesis that inter-country differences in growth rates is influenced more by factors that have been found to explain manufacturing export growth (i.e., the policy regime) than by resource endowments which are a key determinant of primary export growth. More specifically, while resource endowments is obviously a pre-requisite, differences in country-specific resource endowments is relatively less important in explaining cross-country variation in the growth rate of processed food exports. In this section, we proceed to test this hypothesis formally by undertaking a cross-country econometric analysis.

The variable that we wish to explain is the annual growth rate of processed food exports averaged over the period 1970-1994 (denoted by GPF). The explanatory variables are outward-orientation (openness) of the policy regime $(O P E N)$, agricultural resource endowment $(\mathrm{RE})$, level of per capita income $(Y)$ and the growth rate of per capita income $(G Y)$. As regards $O P E N$, we postulate that the more outward-oriented the policy regime of a country, the greater the ability to exploit new trading opportunities emerging in world markets and thus higher the export growth rate. The size and growth of the domestic market (as proxied by $Y$ and $G Y$ respectively), are expected to have a positive influence on export growth. This may emanate from both the direct demand effect on production as well as the generation of investible funds. The general model is:

$$
\begin{gathered}
G P F=F(Y, G Y, R E, O P E N) \\
f_{1}^{\prime}, \hat{f_{2}}, \hat{f_{3}}, \hat{f_{4}} \geq 0
\end{gathered}
$$

The variable $O P E N$ is measured in terms of a country dummy variable based on the SachsWarner (1995) definition of an 'open economy'. In a comprehensive study of the patterns and chronology of trade policy reforms during the post-war era, Sachs and Warner have 
identified countries with 'closed policy regime' using the following policy criteria: (I) Nontariff barriers cover more than 40 per cent or more of the trade, (ii) Average tariffs of 40 per cent or more, (iii) A black market exchange rate that is depreciated by 20 per cent or more relative to the official exchange rate, on average, during the 1970s or 1980s, (iv) A socialist economic system (as defined by Kornai), and (v) A state monopoly on major exports. A country is defined to be open if none of the above five conditions applies. Based on this characterisation $O P E N$ takes the value one for economies found to be open during most of the period 1970-1994 and zero otherwise. ${ }^{9}$ Initial resource endowments $(R E)$ is proxied by the share of food (both processed and unprocessed) ${ }^{10}$ in total exports in 1970. $Y$ is the level of per capita income (in US\$) in 1971 and $G Y$ is the average annual growth in per capita income for the period 1971-1991. ${ }^{11} \quad R E$ and $Y$ enter in the regression in logarithmic form. In addition to these variables we also included a dummy variable (DUMBGD) to account for Bangladesh to account for the abnormally high export growth rate reported for that country. Summary statistics on $G P F, Y, G Y$ and $R E$ is provided in Table 7.

The regression results are reported in Table 8. The complete model is reported as Equation 1. The coefficient of $R E$ turned out to be statistically insignificant (with the perverse sign) in various alternative specifications, suggesting that resource endowments are not an important explicator of inter-country variation in process food export growth. The lack of statistical significance of coefficients on $Y$ and $G Y$ reflects strong collinearity between the two variables. By including these two variables separately in alternative regression runs, we found $G Y$ to be the superior explicator of the two in terms of the $\mathrm{F}$ test. The final regression estimated after omitting $R E$ and $Y$ is reported as equation 2. The regressions are statistically significant at the one per cent level (in terms of the $\mathrm{F}$ test for the overall fit) and performs well by all standard diagnostic tests relevant for a crosssectional regression analysis of this nature.

\footnotetext{
9 The open economies are: Bolivia, Chile, Indonesia, Ivory Coast, Korea, Sri Lanka, Malaysia, Thailand and Taiwan.

${ }^{10}$ Corresponding to SITC categories 0,1 and 4.

11 Data on per capita income is obtained from World Bank (1994) .
} 
Our preferred model (Equation 2), explains 57 per cent of the variation in crosscountry growth rates of processed food exports. The coefficient of OPEN is statistically significant at the one per cent level with the expected (positive) sign. All in all, according to the regression results it is the nature of the policy regime and not the initial resource endowment which is crucial in explaining inter-country differentials in growth performance in processed food exports. ${ }^{12}$ We also note that the coefficient on GY is statistically significant at the 10-percent level with the expected sign. The result is consistent with the hypothesis that the expansion in the domestic economy provides a conducive setting for the emergence of agro-based food industries. The dummy variable for Bangladesh (DUMBGD) is found to be significant at the one per cent level - as has been observed in Table 1, the growth rate of processed food exports for Bangladesh is the highest in our sample of countries; yet Bangladesh had relatively slow growth in per capita income and a closed trade regime for the period under consideration.

\section{Conclusions}

This study has sought to document and analyse at some length a hitherto neglected new development in world trade, namely the increasing importance of processed food and the new opportunities for developing countries in this sphere. In the absence of any previous systematic analysis, our study has essentially been preliminary and exploratory in nature. Further research is needed to shed light on the developmental implications of this emerging phenomenon for developing countries focusing on employment and terms of trade implications and dynamic spread effects. However, our analysis yields a number of inferences relating to trade policy and trade flow analysis.

There is clear evidence that processed food exports have shown greater dynamism compared to primary exports. In some country cases, the degree of dynamism has even been comparable to that of conventionally-defined manufactured goods. Our analysis of

\footnotetext{
12 It should be pointed out that we have used a qualitative measure of 'open-ness'. This has been the general practice in studies which relate the policy regimes to economic performance because the direct measurement of 'out-ward orientation' still remains an unresolved issue. For a succinct treatment of the methodological issues involved, see Pritchett (1996).
} 
the comparative export performance of sample countries clearly suggests that while resource availability is fundamental, export success in this area depend crucially on the nature of domestic policy. Thus, our findings add to the existing evidence against the widely held 'demand-constraint' arguments on the limits to an export-led growth strategy.

There is evidence that these new product lines have many growth-conducive attributes similar to that of standard manufactured goods. These include important learning effects emanating from the mastery of new production technology, higher productivity, and entrepreneurial skills gained through marketing efforts in a competitive environment. Furthermore, given the higher domestic content of production (that is lower import dependence), these products seem to have greater spillover effects on the domestic economy.

The wide-spread practice based largely on the experience of resource-poor NICs has been to consider primary production and the promotion of manufactured exports as largely separate areas of activity. Our results suggest that to maximise gains from exportled industrialisation, these two areas should be viewed as a continuum in the development process.

In many developing countries, it has become fashionable to play overwhelming emphasis on the promotion of 'new' labour-intensive manufactured exports while neglecting or paying inadequate attention to opportunities for the promotion of agro-based industrial activities. This policy bias is evident both in various export incentive policies and in policies relating to the approval and monitoring of foreign investment. The study suggests that such a bias is significantly, if not totally, rooted in the standard (SITC based) classification procedure adopted in trade flow analysis. There is a clear case, then, for a broader and disaggregated treatment of product lines in order to identify new dynamic product areas with a view to providing clear guidance for policy formulation and evaluation. 
Table 1: Merchandise Exports by Major Category and Region

\begin{tabular}{|c|c|c|c|c|c|}
\hline \multicolumn{3}{|l|}{ Categories } & \multirow{2}{*}{$\begin{array}{l}\text { Developed } \\
\text { Countries }\end{array}$} & \multirow{2}{*}{$\begin{array}{l}\text { Developing } \\
\text { Countries }\end{array}$} & \multirow{2}{*}{$\begin{array}{l}\text { World } \\
268224\end{array}$} \\
\hline Total Exports & US\$ Millions & 1970 & & & \\
\hline & & 1994 & 2869000 & 916146 & 3785581 \\
\hline \multirow[t]{2}{*}{ Manufacturing Exports ${ }^{\mathrm{a}}$} & US\$ Millions & 1970 & 167150 & 10493 & 177644 \\
\hline & & 1994 & 2342000 & 725075 & 3066634 \\
\hline \multirow{2}{*}{$\begin{array}{l}\text { Non-manufacturing } \\
\text { Exports }^{\mathrm{b}}\end{array}$} & US\$ Millions & 1970 & 62608 & 27972 & 90581 \\
\hline & & 1994 & 527875 & 191072 & 718947 \\
\hline Processed Food Exports & US\$ Millions & $\begin{array}{l}1970 \\
1994\end{array}$ & $\begin{array}{l}17251 \\
192020\end{array}$ & $\begin{array}{l}6445 \\
71557\end{array}$ & $\begin{array}{l}23697 \\
263577\end{array}$ \\
\hline \multicolumn{6}{|c|}{$\begin{array}{l}\text { Processed Food as a share } \\
\text { of: }\end{array}$} \\
\hline Total Exports & & $\begin{array}{l}1970 \\
1994\end{array}$ & $\begin{array}{l}7.5 \\
6.7\end{array}$ & $\begin{array}{l}16.8 \\
7.8\end{array}$ & $\begin{array}{l}8.8 \\
7.0\end{array}$ \\
\hline Non-mfg. Exports & & $\begin{array}{l}1970 \\
1994\end{array}$ & $\begin{array}{l}27.6 \\
36.4\end{array}$ & $\begin{array}{l}23.0 \\
37.5\end{array}$ & $\begin{array}{l}26.2 \\
36.7\end{array}$ \\
\hline
\end{tabular}

Note: a. SITC 5 through 8 less 68.

b. Total non-oil export less manufacturing exports as defined in (b).

Source: UN trade data (Series D) tapes (IEDB), authors' calculations. 
Table 2: Processed Food Exports and Growth Rate of Exports by Category

\begin{tabular}{|c|c|c|c|c|c|c|c|}
\hline \multirow[b]{2}{*}{ Country/Country group } & \multicolumn{4}{|c|}{ Processed food } & \multicolumn{3}{|c|}{ Annual compound growth } \\
\hline & $\begin{array}{l}1970 \\
\text { US\$mn. }\end{array}$ & $\%$ & $\begin{array}{l}1994 \\
\text { US\$mn }\end{array}$ & $\%$ & $\begin{array}{l}\text { Processed } \\
\text { food }\end{array}$ & $\begin{array}{l}\text { Primary } \\
\text { products }^{\mathrm{a}}\end{array}$ & $\begin{array}{l}\text { Manufa- } \\
\text { cturing }\end{array}$ \\
\hline Low-income Countries & 707.0 & 17.7 & 4686.9 & 10.2 & 3.4 & 1.6 & 4.8 \\
\hline Burundi & 0.2 & -- & 6.3 & -- & 13.7 & 5.1 & 11.8 \\
\hline Bangladesh & $5.1^{\mathrm{b}}$ & $0.1^{\mathrm{b}}$ & 319.0 & 0.7 & $21.8^{\mathrm{c}}$ & $0.7^{\mathrm{c}}$ & $14^{\mathrm{c}}$ \\
\hline Cameroon & 24.4 & 0.6 & 36.8 & 0.1 & 1.7 & 7.5 & 3.8 \\
\hline Ghana & 33.4 & 0.8 & 119.4 & 0.3 & 5.3 & 3.3 & 21.4 \\
\hline Honduras & 19.3 & 0.5 & 148.0 & 0.3 & 8.5 & 4.4 & 7.7 \\
\hline India & 210.8 & 5.3 & 2283.6 & 5.0 & 9.9 & 6.4 & 12.3 \\
\hline Ivory Coast & 46.9 & 1.2 & 409.8 & 0.9 & 9.0 & 7.1 & 9.0 \\
\hline Kenya & 19.0 & 0.5 & 140.3 & 0.3 & 8.3 & 7.7 & 9.3 \\
\hline Madagascar & 23.3 & 0.6 & 88.6 & 0.2 & 5.6 & 2.5 & 5.8 \\
\hline Nicaragua & 54.3 & 1.4 & 148.7 & 0.3 & 4.2 & 2.0 & 1.9 \\
\hline Nigeria & 78.4 & 2.0 & 103.2 & 0.2 & 1.1 & -0.1 & 15.6 \\
\hline Pakistan & 39.1 & 1.0 & 313.0 & 0.7 & 8.7 & 3.6 & 11.6 \\
\hline Sri Lanka & 21.7 & 0.5 & 142.6 & 0.3 & 7.8 & 3.6 & 25.8 \\
\hline Sudan & 16.1 & 0.4 & 48.0 & 0.1 & 4.6 & 0.4 & 17 \\
\hline Senegal & 89.6 & 2.2 & 300.5 & 0.7 & 5.0 & 3.4 & -0.5 \\
\hline Tanzania & 21.2 & 0.5 & 70.2 & 0.2 & 5.0 & 2.5 & 3.6 \\
\hline Zambia & 4.3 & 0.1 & 8.9 & -- & 3.1 & -0.8 & 14.4 \\
\hline Middle-income Countries & 1314.0 & 32.9 & 17404.5 & 37.9 & 4.7 & 3.1 & 8.2 \\
\hline Bolivia & 1.0 & -- & 136.6 & 0.3 & 20.5 & 3.8 & 15 \\
\hline Colombia & 39.2 & 1.0 & 662.3 & 1.4 & 11.8 & 7.9 & 16.8 \\
\hline Costarica & 39.0 & 1.0 & 326.6 & 0.7 & 8.9 & 10.2 & 14.6 \\
\hline Dominican Rep. & 133.2 & 3.3 & 372.2 & 0.8 & 4.3 & 6.8 & 24.6 \\
\hline El Salvador & 19.9 & 0.5 & 133.6 & 0.3 & 7.9 & 3.3 & 7.1 \\
\hline Guatemala & 46.6 & 1.2 & 379.9 & 0.8 & 8.7 & 5.6 & 7.3 \\
\hline Indonesia & 64.6 & 1.6 & 3402.1 & 7.4 & 16.5 & 9.5 & 31 \\
\hline Peru & 406.8 & 10.2 & 1145.8 & 2.5 & 4.3 & 5.1 & 15.5 \\
\hline Philippines & 359.9 & 9.0 & 1486.2 & 3.2 & 5.9 & 9.3 & 17.8 \\
\hline Thailand & 60.2 & 1.5 & 7097.4 & 15.5 & 19.9 & 8.9 & 28.8 \\
\hline Tunisia & 20.4 & 0.5 & 187.2 & 0.4 & 9.2 & 8.0 & 19.2 \\
\hline Turkey & 123.2 & 3.1 & 2074.7 & 4.5 & 11.8 & 7.8 & 23 \\
\hline High-income Countries & 1975.1 & 49.4 & 23814.5 & 51.9 & 4.5 & 2.5 & 14.5 \\
\hline Argentina & 648.5 & 16.2 & 4611.7 & 10.0 & 8.2 & 6.7 & 12.7 \\
\hline Brazil & 528.2 & 13.2 & 8390.1 & 18.3 & 11.5 & 7.2 & 17.4 \\
\hline Chile & 33.0 & 0.8 & 2025.3 & 4.4 & 17.2 & 7.6 & 14.8 \\
\hline Korea & 63.7 & 1.6 & 2192.8 & 4.8 & 14.7 & 12.4 & 20.6 \\
\hline Mexico & 272.4 & 6.8 & 1787.9 & 3.9 & 7.8 & 9.4 & 20 \\
\hline Malaysia & 167.7 & 4.2 & 5041.7 & 11.0 & 14.2 & 6.5 & 24.9 \\
\hline Taiwan & 158.6 & 4.0 & 3753.4 & 8.2 & 13.2 & 12.4 & 18.1 \\
\hline Uruguay & 103.1 & 2.6 & 511.6 & 1.1 & 6.7 & 8.1 & 12 \\
\hline Total sample countries & 3996.1 & 100.0 & 45905.9 & 100.0 & 4.4 & 2.2 & 12.3 \\
\hline All developing countries & 6034.5 & & 61380.3 & & 4.2 & 2.1 & 11.9 \\
\hline
\end{tabular}

Notes: (a) Non-manufacturing exports (as defined in Table 1) less processed food; (b) Figure for 1975; (c) growth rate is for the period 1975-94; -- less than 0.05 percent.

Source: UN trade data (Series D) tapes (IEDB), authors' calculations. 
Table 3 Share of Processed Food in Total (a), Non-manufacturing (b) and ISIC Manufacturing ${ }^{a}$ (c) Exports

\begin{tabular}{|c|c|c|c|c|}
\hline & 1970 & 1980 & 1990 & 1994 \\
\hline \multicolumn{5}{|c|}{ Low-income Countries } \\
\hline \multirow[t]{3}{*}{ Burundi } & a. 1.0 & 0.8 & 3.9 & 6.9 \\
\hline & b. 1.0 & 0.8 & 4.0 & 7.1 \\
\hline & c. 55.5 & 16.4 & 49.4 & 66.6 \\
\hline \multirow[t]{3}{*}{ Bangladesh } & a. 2.4 & 6.1 & 11.7 & 10.7 \\
\hline & b. 26.7 & 19 & 42.5 & 77.6 \\
\hline & c. 2.5 & 8.3 & 13.8 & 11 \\
\hline \multirow[t]{3}{*}{ Cameroon } & a. 10.8 & 11.4 & 7 & 3.1 \\
\hline & b. 11.8 & 12 & 8.4 & 3.2 \\
\hline & c. 56.0 & 67.7 & 29.2 & 43.6 \\
\hline \multirow[t]{3}{*}{ Ghana } & a. 7.8 & 8.7 & 9.3 & 9 \\
\hline & b. 7.9 & 8.8 & 11 & 12.1 \\
\hline & c. 94.4 & 90.4 & 37.3 & 26.1 \\
\hline \multirow[t]{3}{*}{ Honduras } & a. 11.8 & 18.8 & 17.7 & 24.2 \\
\hline & b. $\quad 12.9$ & 21.5 & 19.6 & 28.2 \\
\hline & c. 58.4 & 60.0 & 65.3 & 62.8 \\
\hline \multirow[t]{3}{*}{ India } & a. $\quad 10.5$ & 10.5 & 7.2 & 8.8 \\
\hline & b. $\quad 21.9$ & 25.5 & 26.5 & 39.5 \\
\hline & c. 16.9 & 15.1 & 9.0 & 10.2 \\
\hline \multirow[t]{3}{*}{ Ivory Coast } & a. 10.1 & 14.0 & 20.9 & 14.7 \\
\hline & b. $\quad 10.7$ & 14.7 & 23.8 & 16.1 \\
\hline & c. 62.6 & 74.7 & 62.9 & 62.8 \\
\hline \multirow[t]{3}{*}{ Kenya } & a. $\quad 10.7$ & 10.2 & 11.6 & 11.6 \\
\hline & b. 12.5 & 12.5 & 17.6 & 14.3 \\
\hline & c. 43.1 & 35.8 & 25.5 & 37.6 \\
\hline \multirow[t]{3}{*}{ Madagascar } & a. 16.8 & 15.3 & 25.3 & 27.3 \\
\hline & b. $\quad 18.1$ & 16.4 & 29.6 & 31.3 \\
\hline & c. 69.0 & 69.7 & 63.3 & 67.9 \\
\hline \multirow[t]{3}{*}{ Nicaragua } & a. 31.1 & 31.3 & 40.5 & 43.2 \\
\hline & b. 37.1 & 36.5 & 44.3 & 49.7 \\
\hline & c. 66.0 & 68.9 & 82.4 & 76.9 \\
\hline \multirow[t]{3}{*}{ Nigeria } & a. $\quad 15.3$ & 11.5 & 9.3 & 11.5 \\
\hline & b. $\quad 15.5$ & 12.7 & 15.4 & 19.8 \\
\hline & c. 89.8 & 55.8 & 18.9 & 21.5 \\
\hline \multirow[t]{3}{*}{ Pakistan } & c. 5.7 & 4.1 & 3.3 & 4.3 \\
\hline & b. $\quad 13.5$ & 8.5 & 16.1 & 34.6 \\
\hline & c. 9.0 & 7.3 & 3.9 & 4.7 \\
\hline \multirow[t]{3}{*}{ Sri Lanka } & a. 6.5 & 2.6 & 2.8 & 4.5 \\
\hline & b. 6.6 & 3.3 & 6.1 & 16.4 \\
\hline & c. 82.2 & 10.6 & 5.0 & 5.8 \\
\hline \multirow[t]{3}{*}{ Sudan } & a. $\quad 5.5$ & 9.6 & 12.7 & 13.4 \\
\hline & b. 5.5 & 9.6 & 13.1 & 13.8 \\
\hline & c. $\quad 98.7$ & 91.8 & 80.3 & 79.7 \\
\hline \multirow[t]{3}{*}{ Senegal } & a. $\quad 57.5$ & 49.8 & 57.8 & 73.7 \\
\hline & b $\quad 71.3$ & 61.2 & 77.8 & 78.8 \\
\hline & b. 74.8 & 72.9 & 69.2 & 91.9 \\
\hline
\end{tabular}


Table 3 (Continued)

\begin{tabular}{|c|c|c|c|c|}
\hline \multirow[t]{3}{*}{ Tanzania } & a. 9.6 & 7.7 & 11.0 & 15.7 \\
\hline & b. 11.1 & 9.0 & 12.8 & 18.6 \\
\hline & c. 41.4 & 34.1 & 44.4 & 49.6 \\
\hline \multirow[t]{3}{*}{ Zambia } & a. $\quad 0.4$ & 1.5 & 0.9 & 1.0 \\
\hline & b. $\quad 0.4$ & 1.5 & 0.9 & 1.1 \\
\hline & c. 72.9 & 31.8 & 21.2 & 15.0 \\
\hline \multicolumn{5}{|c|}{ Middle-income Countries } \\
\hline \multirow[t]{3}{*}{ Bolivia } & a. $\quad 0.5$ & 7.3 & 9.9 & 15.2 \\
\hline & b. $\quad 0.5$ & 7.6 & 10.6 & 21.1 \\
\hline & c. 12.7 & 65.6 & 61.4 & 35.3 \\
\hline \multirow[t]{3}{*}{ Colombia } & a. 6.0 & 8.8 & 8.8 & 8.7 \\
\hline & b. 6.6 & 11.0 & 13.6 & 15.2 \\
\hline & c. 40.2 & 30.3 & 20.0 & 16.7 \\
\hline \multirow[t]{3}{*}{ Costa Rica. } & a. 17.0 & 16.1 & 13.9 & 9.4 \\
\hline & b. 20.9 & 22.5 & 19.0 & 16.1 \\
\hline & c. 47.5 & 36.1 & 33.9 & 18.5 \\
\hline \multirow[t]{3}{*}{ Dominican Republic } & a. 62.3 & 52.2 & 15.9 & 10.3 \\
\hline & b. 64.6 & 68.4 & 55.8 & 49.7 \\
\hline & c. 94.5 & 68.9 & 18.2 & 11.5 \\
\hline \multirow[t]{3}{*}{ El Salvador } & a. 8.8 & 8.6 & 10.3 & 16.5 \\
\hline & b. 12.3 & 13.6 & 16.7 & 30 \\
\hline & c. 23.3 & 19.2 & 21.2 & 26.9 \\
\hline \multirow[t]{3}{*}{ Guatemala } & a. 16.1 & 13.8 & 23.9 & 25.8 \\
\hline & b. 22.3 & 18.2 & 31.9 & 37.9 \\
\hline & c. 36.5 & 36.1 & 48.9 & 44.7 \\
\hline \multirow[t]{3}{*}{ Indonesia } & a. 9.1 & 11.8 & 12.2 & 11.3 \\
\hline & b. 9.3 & 12.8 & 32.6 & 35.7 \\
\hline & c. 84.2 & 59.2 & 16.3 & 14.1 \\
\hline \multirow[t]{3}{*}{ Peru } & a. 39.2 & 13.7 & 19.3 & 29.6 \\
\hline & b. 39.8 & 17.4 & 24.2 & 35.1 \\
\hline & c. 96.5 & 39.2 & 48.5 & 65.2 \\
\hline \multirow[t]{3}{*}{ Philippines } & a. 34.5 & 28.6 & 15.6 & 11.5 \\
\hline & b. $\quad 37.4$ & 36.3 & 25.4 & 20.8 \\
\hline & c. 82.0 & 57.4 & 28.7 & 20.6 \\
\hline \multirow[t]{3}{*}{ Thailand } & a. 8.8 & 13.5 & 18.9 & 15.9 \\
\hline & b. 9.2 & 18 & 51.9 & 58.6 \\
\hline & c. 65.1 & 34.9 & 22.9 & 17.9 \\
\hline \multirow[t]{3}{*}{ Tunisia } & a. 11.5 & 2.4 & 5.2 & 4.2 \\
\hline & b. 14.3 & 3.7 & 17.7 & 18.2 \\
\hline & c. 36.8 & 6.1 & 6.8 & 5.1 \\
\hline \multirow[t]{3}{*}{ Turkey } & a. 21.0 & 15.2 & 9.2 & 11.6 \\
\hline & b. 23.0 & 20.9 & 30.1 & 43.8 \\
\hline & c. 70.1 & 35.8 & 11.7 & 13.6 \\
\hline
\end{tabular}


Table 3 (Continued)

High-income Countries

Argentina

a. $\quad 36.7$

29.2

32.2

32.6

b. 42.7

38.4

51.5

c. 72.5

54.9

47.0

47.0

Brazil

a. 19.4

31.3

50.5

19.7

b. 22.4

50.4

22.6

44.9

c. 59.3

45.2

Chile

a. 2.7

10.3

26.0

b. 2.8

11.4

18.4

c. 38.2

52.8

22.1

Korea

a. 7.7

6.6

64.4

b. 33.6

6.9

48.2

29.9

14.3

$55.8 \quad 52.1$

c. 9.1

6.9

2.3

3.0

47.0

Mexico

a. 23.3

9.5

b. 35.1

19.9

15.3

55

$\begin{array}{ll}3.1 & 2.4 \\ 6.8 & 3.3\end{array}$

c. 41.0

16.5

22.0

39.9

22.2

27

$8.9 \quad 3.6$

Malaysia

a. 10.7

11.2

9.3

b. 11.5

32.8

45.1

c. 60.3

7.6

14.6

10.4

Taiwan

a. 11.2

70.3

3.8

4.1

b. 46.9

54.9

51.6

c. 12.8

7.9

3.9

4.3

Uruguay

a. 44.3

29.9

28.5

26.7

b. 55.4

48.1

46.6

46.8

c. 68.9

44

42.3

38.3

Note: a. Manufacturing defined as all commodities belonging to Section 3 of the International Standard Industry Classification (ISIC).

Source: UN trade data (Series D) tapes (IEDB), authors' calculations. 
Table 4 Composition of Processed Food Exports from Developing Countries (percentage shares)

\begin{tabular}{lllll}
\hline Categories of Processed Food & 1970 & 1980 & 1990 & 1994 \\
\hline 1. Processed Meat Products & 13.7 & 7.8 & 8.0 & 8.4 \\
2. Dairy Products & 0.4 & 0.5 & 0.9 & 0.9 \\
3. Processed Fish Products & 8.8 & 15.1 & 29.1 & 30.7 \\
4. Flour and Cereals & 1.1 & 1.5 & 2.2 & 3.0 \\
5. Preserved Fruits & 4.4 & 4.4 & 7.9 & 5.4 \\
6. Preserved Vegetables & 33.6 & 35.2 & 15.8 & 13.1 \\
7. Sugar and Molasses & 31.0 & 31.4 & 10.4 & 8.1 \\
8.CoffeeExtracts and Chocolates & 2.9 & 4.8 & 2.9 & 2.7 \\
9. Preserved Animal Feeds & 13.5 & 10.1 & 10.8 & 9.4 \\
10. Margarine and Food Preparations & 0.8 & 1.2 & 1.9 & 2.5 \\
11. Beverages & 4.0 & 1.8 & 3.0 & 3.5 \\
12. Tobacco Products & 6.1 & 5.2 & 7.6 & 7.6 \\
13. Animal Oils & 1.0 & 0.3 & 0.2 & 0.2 \\
14. Vegetable Oils & 9.6 & 12.1 & 9.6 & 12.5 \\
\hline
\end{tabular}

Source: UN trade data (Series D) tapes (IEDB), authors' calculations. 
Table 5: Share (\%) of Processed Fish and Preserved Fruit in Total Processed Food Exports ${ }^{a}$ by Country

\begin{tabular}{|c|c|c|c|c|}
\hline \multirow[t]{2}{*}{ Countries } & \multicolumn{2}{|c|}{ Processed Fish } & \multicolumn{2}{|c|}{ Preserved Fruit } \\
\hline & 1970 & 1994 & 1970 & 1994 \\
\hline \multicolumn{5}{|l|}{ Low-income } \\
\hline \multicolumn{5}{|l|}{ Countries } \\
\hline Burundi & 37.8 & 8.1 & .. & .. \\
\hline Bangladesh & 97.1 & 98.1 & .. & .. \\
\hline Cameroon & 4.6 & 4.1 & .. & .. \\
\hline Ghana & .. & 44.1 & 2.7 & 0.2 \\
\hline Honduras & 7.2 & 50.6 & 11.2 & 2.9 \\
\hline India & 19.5 & 49.0 & 0.9 & 1.7 \\
\hline Ivory Coast & 5.4 & 34.2 & 23.6 & 0.8 \\
\hline Kenya & 1.6 & 43.6 & 12.3 & 41.9 \\
\hline Madagascar & 13.2 & 68.7 & 0.1 & 8.3 \\
\hline Nicaragua & 11.3 & 35.7 & .. & 0.1 \\
\hline Nigeria & 0.3 & 45.5 & .. & 0.1 \\
\hline Pakistan & 54.4 & 45.7 & .. & 0.5 \\
\hline Sri Lanka & 4.1 & 44.6 & .. & 1.6 \\
\hline Sudan & 0.1 & 0.3 & .. & 0.1 \\
\hline Senegal & 9.0 & 66.8 & 1.2 & .. \\
\hline Tanzania & 10.5 & 39.5 & 0.6 & .. \\
\hline Zambia & 1.0 & 2.7 & .. & 0.2 \\
\hline \multicolumn{5}{|c|}{ Middle-income } \\
\hline \multicolumn{5}{|l|}{ Countries } \\
\hline Bolivia & 0.4 & 0.1 & .. & 4.7 \\
\hline Colombia & 12.3 & 38.9 & 0.9 & 1.5 \\
\hline Costa Rica & 4.7 & 26.7 & 1.6 & 18.7 \\
\hline Dominican Rep. & 0.1 & 1.5 & 0.2 & 4.1 \\
\hline El Salvador & 26.5 & 23.4 &.. & 0.2 \\
\hline Guatemala & 6.0 & 8.3 & 3.6 & 2.0 \\
\hline Indonesia & 8.3 & 46.5 &.. & 1.7 \\
\hline Peru & 1.6 & 14.7 &.. & 0.7 \\
\hline Philippines & 0.6 & 35.8 & 7.5 & 13.0 \\
\hline Thailand & 26.5 & 58.9 & 4.5 & 7.7 \\
\hline Tunisia & 12.6 & 42.2 & 7.7 & 0.4 \\
\hline Turkey & 5.4 & 3.4 & 2.0 & 13.7 \\
\hline \multicolumn{5}{|l|}{ High-income } \\
\hline Countries & & & & \\
\hline Argentina & 0.6 & 15.7 & 0.9 & 2.4 \\
\hline Brazil & 3.6 & 2.1 & 4.3 & 12.5 \\
\hline Chile & 27.2 & 39.8 & 4.4 & 7.7 \\
\hline Korea & 64.1 & 63.9 & 0.4 & 1.3 \\
\hline Mexico & 26.2 & 25.6 & 9.8 & 9.1 \\
\hline Malaysia & 19.5 & 6.4 & 9.2 & 0.9 \\
\hline Taiwan & 14.3 & 44.5 & 16.9 & 2.4 \\
\hline Uruguay & 0.7 & 16.0 &.. & 0.5 \\
\hline
\end{tabular}

Note: a. .. denotes negligible. b. Figure refers to 1975.

Source: UN trade data (Series D) tapes (IEDB), authors' calculations. 
Table 6: Capital Intensity of Production in Malaysian Manufacturing (selected 5-digit SIC industries), 1992

\begin{tabular}{lll}
\hline ISIC & Industry & Fixed assets per \\
code & worker & \\
& (Malaysian Ringgits)
\end{tabular}

\begin{tabular}{lll}
\hline & Resource-based manufactures & \\
31131 & Canned pineapple & 17038 \\
31139 & Other processed fruit & 26235 \\
31140 & Canned and preserved fish & 27729 \\
31151 & Coconut oil & 27057 \\
31152 & Palm oil & 98628 \\
31153 & Palm kernel oil & 100221 \\
31164 & Sago and tapioca factories & 23219 \\
31190 & Chocolate & 67658 \\
31214 & Meehoon, noodles and related products & 23030 \\
33112 & Plywood, hard board and particle board & 42415 \\
33200 & Furniture and fixtures & 20483 \\
35599 & Rubber products & 40153 \\
36100 & Pottery, china and earthenware & 25629 \\
37201 & Tin smelting and other non-ferrous metal & 81221 \\
& & \\
& Conventional (SITC-based) manufactures & \\
32120 & Made-up textile goods & 15104 \\
32130 & Knitting mills & 24269 \\
32201 & Wearing apparel & 8179 \\
32330 & Leather goods & 16736 \\
32400 & Footwear & 14446 \\
38320 & Radio and television sets & 29277 \\
38322 & Magnetic tapes & 128426 \\
38329 & Semiconductors and electronics & 34838 \\
39020 & Sporting and athletic goods & 15881 \\
39093 & Toys & 4705 \\
\hline
\end{tabular}

Source: Compiled using data from Malaysian Department of Statistics, Survey of Industry- 1992, Kuala Lumpur. 
Table 7: Summary Statistics

\begin{tabular}{lll}
\hline Variables & Mean & Standard Deviation \\
\hline GPF & 9.4 & 5.2 \\
Y (in log) & 2.9 & 0.4 \\
GY & 2.4 & 1.5 \\
RE $(\%)$ & 46.9 & 27.9
\end{tabular}

Note: GPF = Growth Rate of Processed Food Exports, 1970-94, Y = Per Capita Income (in US \$) in 1971, GY = Growth Rate of Per Capita Output, 1971-91, and RE = Share of Processed and Unprocessed Food in Total Exports.

Sources: GPF and RE: UN trade data ( Series D) tapes (IEDB), Y and GY: World Bank (1994).

\section{Table 8: Regression Results}

\begin{tabular}{lll}
\hline Independent Variables/Test Statistics & Equation 1 & Equation 2 \\
\hline Constant & 4.49 & $5.57^{* *}$ \\
$Y$ & $(0.89)$ & $(4.93)$ \\
& 0.36 & --- \\
$G Y$ & $(0.18)$ & \\
& 0.68 & $0.74^{* *}$ \\
$R E$ & $(1.06)$ & $(1.66)$ \\
& -0.20 & --- \\
OPEN & $(0.36)$ & \\
& $6.27^{* *}$ & $6.44^{* *}$ \\
DUMBGD & $(3.81)$ & $(4.27)$ \\
& $14.81^{* *}$ & $14.96^{* *}$ \\
$N$ & $(3.85)$ & $(4.32)$ \\
$F$ & & \\
$\bar{R}{ }^{2}$ & 37 & 37 \\
S.E. & $9.64^{* * *}$ & $16.96^{* *}$ \\
$R E S E T$ & 0.55 & 0.57 \\
$N O R M$ & 3.50 & 3.40 \\
$H E T$ & 0.98 & 1.91 \\
\hline
\end{tabular}

Notes:

a. Dependent Variable is GPF; b. Figures in brackets indicate t-ratios.

c. $* *$ and $*$ denotes significance at the $1 \%$ and the $10 \%$ level respectively.

d. RESET = Ramsey test for functional form mis-specification; NORM = Jarque-Bera test for normality of error term; and $H E T=$ White test for heteroskedasticity. RESET and HET statistics are based on the F-distribution, while the NORM statistic is distributed as $\chi^{2}$. 


\section{References:}

Amsden, Alice H. and Rolf Van Der Hoeven (1996), "Manufacturing Output, Employment and Real wages in the 1980s: Labour's Lost Until the Century's End", Journal of Development Studies, 32(4), 506-530.

Athukorala, Prema-Chandra (1991) "An Analysis of Demand and Supply Factors in Agricultural Exports from Developing Asian Countries", Weltwirtschaftliches Archiv, 127(4), 764- 91.

Edwards, Sebastian (1995), Crisis and Reform in Latin America: From despair to Hope, New York: Oxford University Press.

Findlay, Ronald (1985), "Primary Exports, Manufacturing and Development", in Mats Lundahl (ed.), The Primary Sector in Economic Development, London: Croom Helm, 218-233.

Helleiner, Gerald K. (1994), "Introduction" in G.K. Helleiner (ed.) Trade Policy and Industrialization in Turbulent Times, London: Routledge, 1-36.

Islam, Nurul (1988), "Fast-growing Agricultural Exports of Developing Countries", Food Policy, 13, August, 313-16.

---- and Arvind Subramanian (1989), "Agricultural Exports from Developing Countries: Estimates of Income and Price Elasticities of Demand and Supply", Journal of Agricultural Economics, 40(2), 221-31.

Meller, Patricio (1995), "Chilean Export Growth, 1970-90: An Assessment" in G.K. Helleiner (ed.), Manufacturing for Export in the Developing World: Problems and Policies, London: Routlegde, 21-53.

Pritchett, Lant (1996), "Measuring Outward Orientation in LDCs: Can it be done?", Journal of Development Economics, 49, 307-335.

Roemer, Michael (1979), "Resource-based Industrialization in the Developing Countries: A Survey", Journal of Development Economics, 6(2), 163-202.

Sachs, Jeffrey D. and Andrew Warner (1995), "Economic Reforms and the Process of Global Integration", Brookings Papers on Economic Activity, 25th Anniversary Issue, 1-95.

Teitel, Simon (1989) "Industrialisation, Primary Commodities and Exports of Manufactures", in Nurul Islam (ed.), The Balance Between Industry and Agriculture in Economic Development, Basingstoke: Macmillan, 315-341. 
United Nations (1994), Yearbook of Industrial Statistics, New York.

World Bank (1994a), World Development Report 1994, Washington, D.C..

---- (1994b), World Tables, Washington D.C.. 


\section{Appendix A1}

List of Commodities included in the definition of Processed Food ( 5 digit SITC codes in brackets)

\section{Processed meat products}

Bovine meat fresh, frozen (0111)

Mutton etc frsh, chilled and frozen (0112)

Pig meat fresh, chlled, frozen (0113)

Poultry fresh chilled,frozen (0114)

Edible offal fresh,chilled and frozen (0116)

Meat fresh, chilled and frozen, nes (0118)

Pig meat dried, salted and smoked (0121)

Meat dried, salted and smoked nes (0129)

Meat extracts and juices (0133)

Sausages including tinned (0134)

Meat prepared d, preserved nes (0138)

\section{Dairy products}

Milk cream evaporated, condensed (0221)

Milk and cream dry (0222)

Milk and cream fresh (0223)

Butter (0230)

Cheese and curd (0240)

\section{Processed fish products}

Fish fresh, chilled, frozn (0311)

Fish salted, dried, smoked (0312)

Shell fish fresh, frozen (0313)

Fish etc tinned, prepared (0320)

\section{Flour and cereals}

Wheat etc meal or flour (0460)

Meal and flour non-wheat (0470)

Prepd breakfast food etc (0481)

Malt including flour (0482)

Macaroni,spaghetti etc (0483)

Bread, biscuit, cake etc (0484)

Cereal etc preps nes (0488) 


\section{Preserved fruits}

Fruit preserved by sugar (0532)

Fruit,jams,jellies etc (0533)

Fruit or vegetable juice (0535)

Fruit temporarily presvd (0536)

Fruit nuts nes preserved (0539)

\section{Preserved vegetables}

Vegetables simply presvd (0546)

Veg dried excl legumes (0551)

Flour etc of fruit and vegetable (0554)

Vegtbles preserved, prepared nes (0555)

\section{Sugar and molasses}

Beet and cane sugar (0611)

Refined sugar etc (0612)

Molasses (0615)

Natural honey (0616)

Sugars and syrups nes (0619)

Sugar preps non-choclate (0620)

\section{Coffee extracts, cocoa and chocolates}

Coffee essences, extracts (0713)

Cocoa powder unsweetened (0722)

Cocoa butter and paste (0723)

Chocolate and products (0730)

\section{Preserved animal feeds}

Bran,pollard,sharps, etc (0812)

Vegetable oil residues (0813)

Meat or fish meal fodder (0814)

Food waste and feed nes (0819)

10. Margarine and food preparations

Margarine,edible fat nes (0914)

Food preparations nes (0990)

\section{Beverages}

Non-alc beverages nes (1110)

Wine of fresh grapes etc (1121)

Beer, ale, stout, porter (1123)

Distilled alcoholic bevs (1124) 


\section{Tobacco products}

Cigars,cheroots (1221)

Cigarettes (1222)

Other mfd tobacco (1223)

\section{Animal oils}

Oils of fish, whales etc (4111)

Animal oil etc, excl lard (4113)

\section{Vegetable oils}

Soya bean oil (4212)

Groundnut, peanut oil (4214)

Rape, colza, mustard oils (4217)

Linseed oil (4221)

Palm oil (4222)

Coconut (copra) oil (4223)

Castor oil (4225)

Fixed vegetable oil nes (4229)

Procesd anml, vegetable oil nes (4311)

Hydrogenated oil and fat (4312)

Fatty acids etc (4313)

Animal, vegetable waxes (4314) 